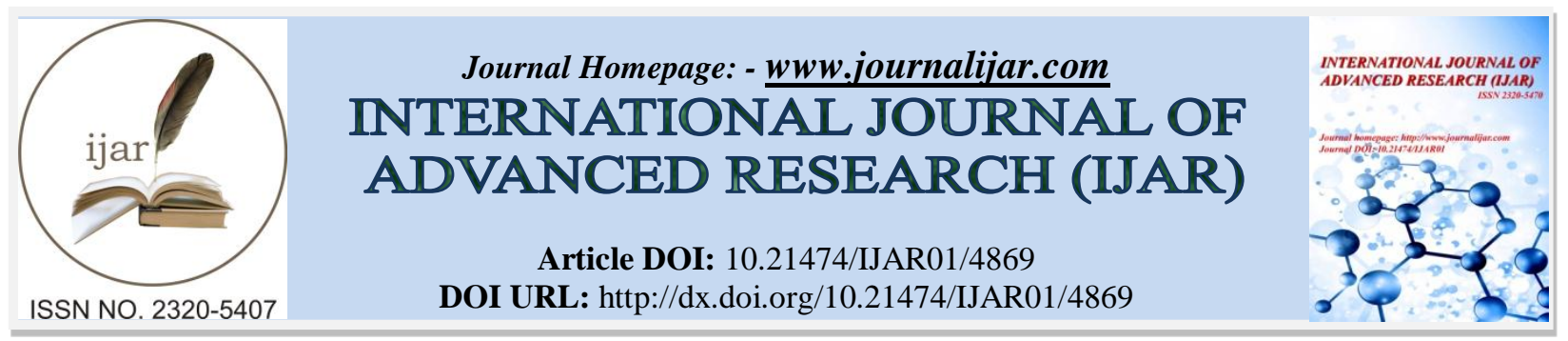

RESEARCH ARTICLE

\title{
PHYSIOLOGICAL VARIATION AND ACCUMULATION OF METALS IN TWO GROWTH FORMS OF LICHENS GROWING AROUND PANKI THERMAL POWER PLANT OF UTTAR PRADESH, INDIA.
}

\section{Namita Gupta ${ }^{1}$, Shiv Kumar Dwivedi ${ }^{1}$ and Dalip Kumar Upreti ${ }^{2}$.}

1. Department of Environmental Science, Babasaheb Bhimrao Ambedkar (A Central) University, Raebareli road, Lucknow-226025.

2. Lichenology Laboratory, CSIR-National Botanical Research Institute, Rana Pratap Marg, Lucknow-226001.

\section{Manuscript Info}

……

Manuscript History

Received: 17 May 2017

Final Accepted: 19 June 2017

Published: July 2017

Key words:-

Lichens, Environment, Air Pollution, metals, Biomonitors, Thermal power plants.

\section{Abstract}

The present study deals with an analysis of inorganic pollutants, their possible sources and effect on naturally growing Pyxine cocoes (Sw.) Nyl., a foliose lichen and Rinodina sophodes (Ach.) A. Massal., a crustose lichens around Panki Thermal Power Plant, Kanpur, Uttar Pradesh. The east direction of the thermal power plant which experiences heavy traffic activity showed complete absence of lichens while west side has the maximum number of lichen thalli.

The result indicated that correlation analysis revealed that chlorophyll a, b, total chlorophyll, carotenoid, chlorophyll degradation was significantly correlated with each other whereas protein content showed negative correlation with chlorophyll a (-0.981), chlorophyll b $(-0.97)$, total chlorophyll (-0.976), carotenoid (-0.935) and chlorophyll degradation (-0.994) in $R$. sophodes. All metals studied for both the species showed positive correlation matrix between the metals. The highest concentration of $\mathrm{Fe}, \mathrm{Mn}, \mathrm{Zn}$ and $\mathrm{Pb}$ were found at highly polluted areas with heavy traffic and road construction. The present study has established the utility of crustose and foliose growth forms of lichens in monitoring of environmental pollution in an area

Copy Right, IJAR, 2017,. All rights reserved.

\section{Introduction:-}

The Kanpur city is situated in the tropical Gangetic plains of India, has an area of over $300 \mathrm{~km}^{2}$ with an approximate population of 3 million inhabitants. It is one of the oldest industrial townships of North India with major industrial and commercial place. It is also known as Leather City of India as it contains a number of the tanneries around the city.

A large number of pollution monitoring studies with higher plants are available in India; however, such studies with utilizing lichens have been started recently. The primary sources of energy in India are renewable resources such as coal and wood its utilization in power generation is emerging as the biggest environmental problem because it emits fly ash, acid precursors, greenhouse gases, non-combustible hydrocarbons, heavy metals and particulates matters. The pollutants emerged can be dispersed to a long distance by wind and ultimately have a negative impact on both biotic and abiotic environment (Cicek et al., 2001). 
Lichens are slow growing and assimilate metals at a rapid rate but release them at a low rate. Metal concentration in lichen thalli have been shown to correlate with atmospheric levels. Lichens were first used as bio-accumulative indicators in relation to point-emission sources, where decreasing metal concentration in species correlated with increasing distance from the source (Burton, 1986).

Lichens are peculiar plants in having special sensitivity for acidic gases but accumulate several organic compounds and elements in a large amount beyond their physiological needs and thus can be utilized as biological indicators of air quality. Lichen have been used as accumulating indicators which provides information especially about the amount of different heavy metals absorbed in the lichen thalli. The epiphytic lichens have been used extensively to monitor air quality around urban areas, industrial sites and to document spatial distribution and accumulation of air borne pollutants (Purvis et al., 2004; Bargagli- Pertrucci, 1915; Singh et al., 1994).

Lichens, a symbiotic association between fungi and algae, are common organisms all around the world and have capacity to colonize on a great diversity of substrates. In the recent years, due to their sensitivity to acidic gases and excellent metal accumulating nature, lichens are presently used for monitoring pollutant in different regions of the world. Lichens have ability to accumulate both organic and inorganic metals beyond their physiological needs.

Biomonitoring studies using lichen have been carried out in different cities of India having varid climatic conditions (Dubey et al., 1999; Upreti and Pandey, 2000; Pandey et al., 2002; Bajpai et al., 2004; Mishra et al., 2003; Saxena et al., 2007; Shukla and Upreti, 2007a, b, 2008; Bajpai et al., 2010 a, b; 2013a, b; Gupta, 2014; Gupta et al., 2015). A single report about the concentration of carbon and sulphur content that affects the physiology of $R$. sophodes, growing naturally in the city of Kanpur is available (Satya and Upreti, 2009; 2015). Lichens are used as passive pollution monitors because they accumulate a variety of pollutants in their thalli at levels well above environmental concentrations and their own physiological needs. The thermal power plants in the country are the major source of power generation which not only deteriorate the natural resources but also affects the human health upto a greater extend.

The present study is aimed to assess the impact of thermal power plant emission on two naturally growing commonly occurring lichen species $P$. cocoes, a foliose and $R$. sophodes, a crustose lichen, to determine the inorganic metals accumulated and changes in their chlorophyll content.

\section{Materials and Methods:- Study Area:-}

Kanpur city, with a population of about 3 million, is situated in North central part of India at $88^{\circ} 22^{\prime} \mathrm{E}$ and $26^{\circ} 26^{\prime} \mathrm{N}$ in Gangetic plain, is the second largest and most populated industrial city in the state of Uttar Pradesh, India (Fig. 1A, B).. Panki thermal power plant is situated in the Panki town of Kanpur district about 20 Kms from Kanpur Railway Station on Kalpi road, between co-ordinates $26^{\circ} 28^{\prime} 35^{\prime \prime} \mathrm{N}$ and $80^{\circ} 14^{\prime} 31^{\prime \prime} \mathrm{E}$ (Fig. 1C). The coal-based Panki thermal power plant has electricity production capacity of $210 \mathrm{MW}(2 \mathrm{x} 105)$. The coal to all units is fed from coal mines of BCCL and ECL by means of railways. The study area is situated in the zone of humid subtropical climate and the year is divided into three seasons: the cold season (November- February), the hot season (March- June) and the monsoon season (July- October). Heavy rainfall (generally 70-80\% of the total rainfall) occurs during the monsoon season in the months of July, August and September. The fast pace of industrialization, urbanization together with the destruction of forest resulted in few scattered, open canopy deciduous forests in the district.

\section{Sample Collection:-}

The area around thermal power plant was randomly surveyed for collection of lichens from 34 localities in all four directions i.e. east, west, north and south of the power plant. Lichens especially, P. cocoes and R. sophodes were growing abundantly in all four directions on the bark of Mangifera indica tree around power plants in all direction except the east direction showed complete absence of lichens (Fig. 1). These species were widely distributed in the area thus both the species were sampled for pigment and metal analysis.

The collected samples were dried and kept inside the paper packet. The lichen samples were determined by their morphological, anatomical and chemical characters by using LABOMED dissecting microscope for external morphology, while LEICA ATC 2000 compound microscope was used for microscopic anatomical details of the samples. The chemical substance present in the lichen thallus were identified through TLC in solvent system A 
(Toluene: 1-4 Dioxane and Acetic acid; 180:60:4) (Orange et al., 2001). The voucher specimens of each species were preserved in the Lichen Herbarium (LWG) of CSIR- National Botanical Research Institute, Lucknow, India.

Pigment Analysis:- The chlorophyll content was calculated from absorbance values at 663 and $645 \mathrm{~nm}$ according to the equation of Arnon (1949). The total carotenoid content was calculated according to Parsons et al. (1984) from absorbance values at 480 and $510 \mathrm{~nm}$.

Chlorophyll Degradation:- The method developed by Ronrn and Galun (1984) was used to measure intensity of the photobiont chlorophyll. The chlorophyll was extracted overnight in the dark in $5.0 \mathrm{ml}$ dimethyl sulfoxide (DMSO, Merck, analytical grade). The ratio of chlorophyll a to phaeophytin a (OD 435/415nm ratio) was determined.

Protein Estimation:- The protein content was measured using Folin phenol as reagents with bovine serum albumin (BSA) as standard and calculations were made from absorbance values at 700nm (Lowry et al., 1951).

Metal Analysis:- The lichen thalli were removed from the bark with sharp knife. The samples (constant weight) were oven dried for $12 \mathrm{hrs}$ at $90^{\circ} \mathrm{C}$. The dried lichen samples $(\mathrm{n}=3)$ were grinded in a mortar pestle $(1.0 \mathrm{~g})$ and each sample was digested in mixture of concentrated $\mathrm{HNO}_{3}$ and $\mathrm{HClO}_{4}(\mathrm{v} / \mathrm{v}, 9: 1)$ for 1 hour. Residues were filtered through Whatman Filter paper No. 42 and diluted up to $25 \mathrm{ml}$ with double distilled water. Analysis was done with ICP MS (Perkin Elmer SCIEX ELAN DRCe). Stock standards were from Merck India and traceable to NIST (National Institute of Standards Technology). Working standards were prepared from the stock using deionised water.

Statistical Analysis:- Differences in chlorophyll response to air pollution and elemental content were compared using One-way analysis of variance (ANOVA) with least significant difference (LSD) and coefficient of variance (CV\%). Pearson correlation was obtained using Statistical program SPSS 16.0.

\section{Results and Discussion:-}

The study area showed occurrence of 8 epiphytic lichens species belonging to 7 genera and 7 families found growing at 34 monitoring sites upto a distance of $20 \mathrm{~km}$ in west, north and south directions of the Panki Thermal Power Plant. Pyxine cocoes and Rinodina sophodes showed their dominance over other species in the area surveyed.

It is clear from the observation that the diversity of lichens increased with increasing distance from the source of pollution. Panki Thermal Power Plant is located about $20 \mathrm{kms}$ from the Kanpur railway station and has the agricultural land and canals as well as flyash dumping sites around the power plant. $P$. cocoes and $R$. sophodes exhibit their presence in west, north and south directions and it is observed that the number of lichen thalli increases with increasing distance from the power plant of which west direction exhibited the maximum number of lichens.

The results of the physiological (Table-1 \& 2) and elemental analysis (Table-3 \& 4) were evaluated by one way ANOVA, thus evaluating the effects of the sampling sites on the bioaccumulation and the physiological status of the photobiont.

\section{Comparative physiological response of $P$. cocoes and $R$. sophodes around Panki Thermal Power Plant, Kanpur:-}

$P$. cocoes (foliose) and $R$. sophodes (crustose) lichen commonly occurring within the contaminated and noncontaminated area were selected for photosynthetic pigment analysis and metal concentration. In $P$. cocoes, chlorophyll a showed minimum concentration at $0.01 \pm 0.002 \mu \mathrm{gg}^{-1}$ in west whereas maximum concentration at $0.02 \pm 0.003 \mu \mathrm{gg}^{-1}$ in south direction. Chlorophyll $\mathrm{b}$ content ranged from $0.00 \pm 0.001 \mu \mathrm{gg}^{-1}$ (west) to $0.01 \pm 0.002$ $\mu g^{-1}$ (south) in the outskirts of thermal power plant. The total chlorophyll (chlorophyll a + chlorophyll b) ranged from $0.01 \pm 0.003{\mu g^{-1}}^{-1}$ in west to $0.02 \pm 0.004{\mu g^{-1}}^{-1}$ in south direction respectively. All the above three photosynthetic parameters showed similar trend of concentration in settling of pigment in lichen thalli.

Highest concentration of carotenoid was detected in P. cocoes found in south $\left(0.01 \pm 0.002 \mu \mathrm{gg}^{-1}\right)$, while lowest concentration was detected in north and west directions $\left(0.01 \pm 0.001 \mu \mathrm{gg}^{-1}\right)$. Chlorophyll degradation concentration was ranged from $0.77 \pm 0.015 \mu \mathrm{gg}^{-1}$ in west to $1.00 \pm 0.011 \mu \mathrm{gg}^{-1}$ in north direction. Protein concentration ranged from $1.31 \pm 0.089 \mu \mathrm{gg}^{-1}$ in west to $1.54 \pm 0.088 \mu \mathrm{gg}^{-1}$ in south direction. The samples collected from the west showed 
lower concentration values of all parameters, while samples from south direction showed higher concentration of all parameters except chlorophyll degradation (Table-1). The east direction showed complete absence of lichens as the sites has residential and commercial areas together with roads with high traffic activity. LSD analysis in $P$. cocoes showed highly significant difference only in chlorophyll degradation at $\mathrm{p}<0.01 \%$ level whereas total chlorophyll and carotenoid showed significant differences at $\mathrm{p}<0.05 \%$ level. Chlorophyll a and $\mathrm{b}$ along with protein estimation showed non-significant difference (Table-1).

Chlorophyll content and its degradation are often used as one of the cheapest and most accurate methods of biomonitoring. $R$. sophodes showed minimum chlorophyll a concentration $\left(0.49 \pm 0.07 \mathrm{\mu gg}^{-1}\right.$ Fresh weight $)$ in west direction whereas maximum concentration $\left(0.79 \pm 0.02 \mu \mathrm{gg}^{-1}\right)$ in north direction. Chlorophyll b content ranged from $0.16 \pm 0.02 \mu \mathrm{gg}^{-1}$ in west to $0.44 \pm 0.06 \mu \mathrm{gg}^{-1}$ in north direction The total chlorophyll (chlorophyll a + chlorophyll b) ranged from $0.65 \pm 0.09 \mu \mathrm{gg}^{-1}$ in west to $1.23 \pm 0.08 \mu \mathrm{gg}^{-1}$ in north direction respectively. According to Carreias et al. (1998), the concentration of total chlorophyll is governed by the ambient environment, anthropogenic sources, vehicular traffic pollution and urban emission. Lowest concentration of carotenoid was detected in samples of $R$. sophodes in west $\left(0.24 \pm 0.05 \mu \mathrm{gg}^{-1}\right)$, while highest concentration was detected in north direction $\left(0.55 \pm 0.02 \mu \mathrm{gg}^{-1}\right)$. The ratio of optical density of chlorophyll samples read at 435 and $415 \mathrm{~nm}$ is the most frequently used parameter for chlorophyll degradation (Garty et al., 2000). Chlorophyll degradation concentration was highest in north decreased with increasing distance in west and south direction from NTPC and it ranged from $0.70 \pm 0.01 \mu \mathrm{gg}^{-1}$ in west to $1.05 \pm 0.01 \mathrm{\mu gg}^{-1}$ in north direction. All the photosynthetic parameters (chl. a, b, total chlorophyll, carotenoid and chlorophyll degradation) showed the same pattern of variation in higher and lower concentration which might be due to effect of wind direction and pollution loads.

Protein concentration ranged from $1.50 \pm 0.17 \mu \mathrm{gg}^{-1}$ in south to $7.19 \pm 0.12 \mu \mathrm{gg}^{-1}$ in west direction. The increased level of protein in the present study, at most contaminated sites corresponds with the findings of Gonzaléz et al. (1996) for the Ramalina ecklonii. The area Airport road Kataraghan Shyam west to thermal power plant; Airport road Kataraghan Shyam west to thermal power plant near Sachendi; Airport road near Sachendi; Aligarh- Kanpur road, Bagdudi Bazar, Amiliha near choubeypur kalan near tatiyaganj; near Panki thermal power plant, Rampur, Bhimsen and Canel road Meharavan Singh Purwa, Patarsa near Mardanpur showed lichen diversity in the areas.

In the present study, the ratio was highly affected at $10 \mathrm{~km}$ to $15 \mathrm{~km}$ radius of Panki thermal power plant in $R$. sophodes, the highest amount of degradation was observed at outskirt of the point sources. LSD analysis in $R$. sophodes at $\mathrm{p}<0.01 \%$ level showed significant difference in chl. a, total chlorophyll, carotenoid, chlorophyll degradation and protein content, while only chl. $\mathrm{b}$ showed significant differences at level of $0.05 \%$ (Table-1).

Correlations of various physiological parameters (Table-2) shows significant correlation of total chlorophyll content with chlorophyll $\mathrm{b}(\mathrm{p}<0.01)$ in $P$. cocoes but $R$. sophodes showed significant correlation of chlorophyll $\mathrm{b}$ with chlorophyll a and total chlorophyll with chlorophyll a and chlorophyll $b$ at $\mathrm{p}<0.05$ level while protein had negative correlation with chlorophyll a, b, total chlorophyll, carotenoid and chlorophyll degradation. Increase in protein due to stressed condition has been reported in higher plants by Neumann et al. (1994). Overall pattern showed the concentration varied with the wind direction of the area as well as increasing trend with the increasing distance from the thermal power plant. In the area with fly ash dumping sites, vehicular exhausts are the main source of metals that can alter the biosynthesis of protein. 


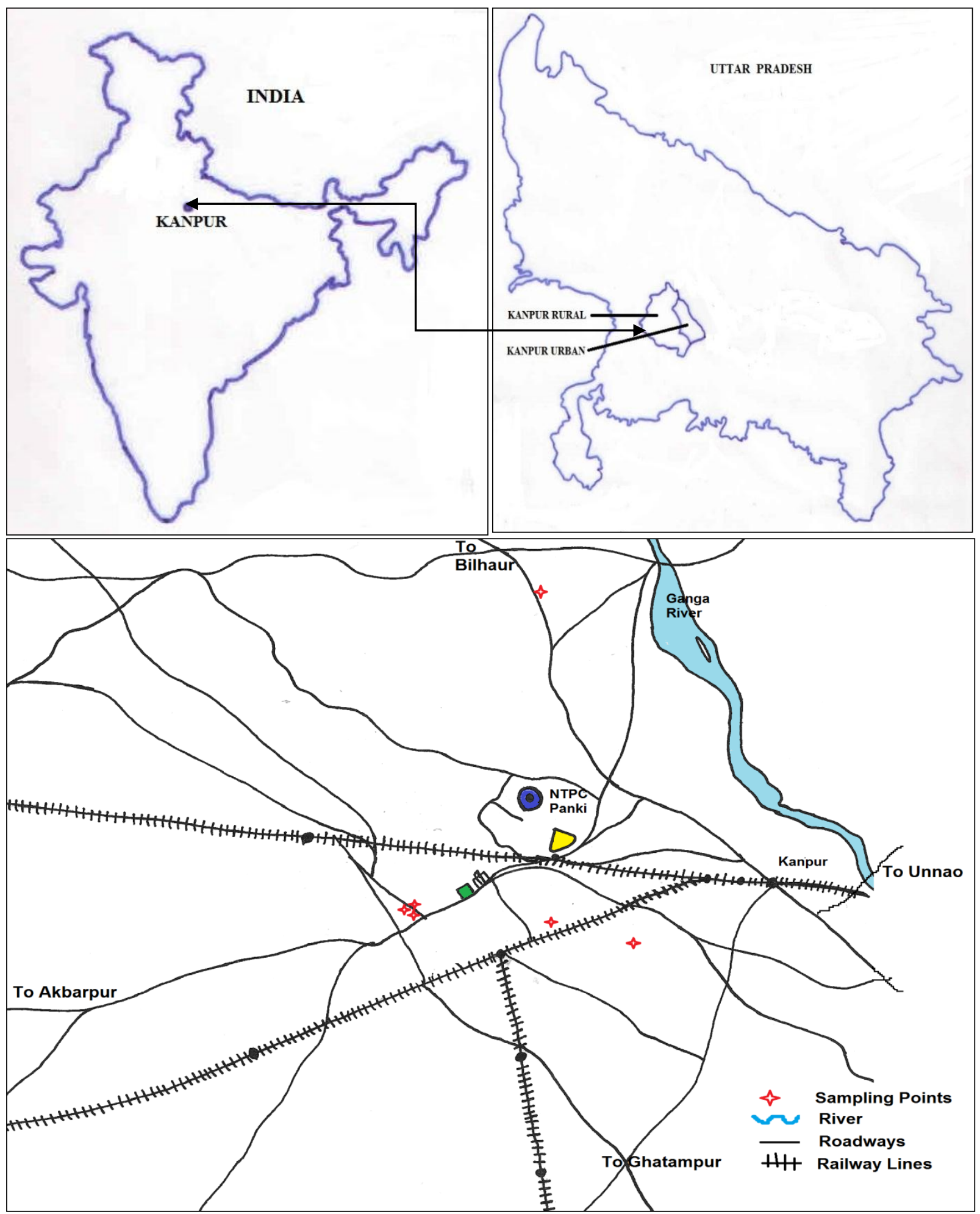

Fig. 1:- (A) Map of India showing Kanpur district; (B) Uttar Pradesh Region; (C) Location of sampling sites around Panki thermal power plant 
Table 1:- Photosynthetic pigment analysis and protein content of lichens around Panki Thermal Power Plant, Kanpur

\begin{tabular}{|c|c|c|c|c|c|c|}
\hline \multirow[t]{2}{*}{ Directions } & \multicolumn{6}{|c|}{ P. cocoes (concentration in $\mu \mathrm{gg}^{-1}$ ) } \\
\hline & Chl. a & Chl. b & Total Chl. & Carotenoid & Chl. deg. & Protein \\
\hline North & $0.01 \pm 0.003$ & $0.01 \pm 0.001$ & $0.02 \pm 0.003$ & $0.01 \pm 0.001$ & $1.00 \pm 0.011$ & $1.35 \pm 0.230$ \\
\hline West & $0.01 \pm 0.002$ & $0.00 \pm 0.001$ & $0.01 \pm 0.003$ & $0.01 \pm 0.001$ & $0.77 \pm 0.015$ & $1.31 \pm 0.089$ \\
\hline South & $0.02 \pm 0.003$ & $0.01 \pm 0.002$ & $0.02 \pm 0.004$ & $0.01 \pm 0.002$ & $0.97 \pm 0.016$ & $1.54 \pm 0.088$ \\
\hline $\begin{array}{l}\text { CV\% } \\
\text { LSD (p< } \\
0.05 \%)\end{array}$ & $\begin{array}{c}21.70 \\
0.005^{\mathrm{NS}}\end{array}$ & $\begin{array}{c}22.01 \\
0.002^{\mathrm{NS}}\end{array}$ & $\begin{array}{c}18.83 \\
0.006^{*}\end{array}$ & $\begin{array}{c}17.42 \\
0.003^{*}\end{array}$ & $\begin{array}{c}1.54 \\
0.025^{* *}\end{array}$ & $\begin{array}{c}10.81 \\
0.269^{\mathrm{NS}}\end{array}$ \\
\hline \multirow[t]{2}{*}{ Directions } & \multicolumn{6}{|c|}{ R. sophodes (concentration in $\mu g^{-1}$ ) } \\
\hline & Chl. a & Chl. b & Total Chl. & Carotenoid & Chl. deg. & Protein \\
\hline North & $0.79 \pm 0.02$ & $0.44 \pm 0.06$ & $1.23 \pm 0.08$ & $0.55 \pm 0.02$ & $1.05 \pm 0.01$ & $1.53 \pm 0.12$ \\
\hline West & $0.49 \pm 0.07$ & $0.16 \pm 0.02$ & $0.65 \pm 0.09$ & $0.24 \pm 0.05$ & $0.70 \pm 0.01$ & $7.19 \pm 0.12$ \\
\hline South & $0.73 \pm 0.10$ & $0.37 \pm 0.12$ & $1.10 \pm 0.22$ & $0.44 \pm 0.13$ & $1.01 \pm 0.01$ & $1.50 \pm 0.17$ \\
\hline $\mathrm{CV} \%$ & 10.92 & 23.87 & 14.52 & 19.05 & 1.15 & 14.10 \\
\hline $\begin{array}{l}\text { LSD }(\mathrm{p}< \\
0.05 \%)\end{array}$ & $0.146^{* *}$ & $0.155^{*}$ & $0.288 * *$ & $0.157 * *$ & $0.021 * *$ & $0.279 * *$ \\
\hline
\end{tabular}

Mean \pm S.D., $n=3$ in $\mu g g^{-1}$

** Significance at the level of $0.01 \%$.

* Significance at the level of $0.05 \%$.

Table 2:- Values of correlation matrix between the physiological parameters studied found in lichen thalli around Panki Thermal Power Plant, Kanpur

\begin{tabular}{|c|c|c|c|c|c|c|}
\hline P.cocoes & Chl.a & Chl.b & Total Chl. & Carotenoid & Chl. deg. & Protein \\
\hline Chl.a & 1 & 0.5 & 0.5 & a & 0.392 & 0.987 \\
\hline Chl.b & & 1 & $1.000 * *$ & .a & 0.993 & 0.634 \\
\hline Total Chl. & & & 1 & .a & 0.993 & 0.634 \\
\hline Carotenoid & & & &. $\mathrm{a}$ &. $\mathrm{a}$ &. $\mathrm{a}$ \\
\hline Chl. deg. & & & & & 1 & 0.537 \\
\hline Protein & & & & & & 1 \\
\hline R. sophodes & Chl.a & Chl.b & Total Chl. & Carotenoid & Chl. deg. & Protein \\
\hline Chl.a & 1 & $.999 *$ & $1.000 *$ & 0.986 & 0.996 & -0.981 \\
\hline Chl.b & & 1 & $1.000 *$ & 0.993 & 0.99 & -0.97 \\
\hline Total Chl. & & & 1 & 0.99 & 0.994 & -0.976 \\
\hline Carotenoid & & & & 1 & 0.968 & -0.935 \\
\hline Chl. deg. & & & & & 1 & -0.994 \\
\hline Protein & & & & & & 1 \\
\hline
\end{tabular}


Table 3:- Metal accumulation in the thalli of lichens around Panki Thermal Power Plant, Kanpur

\begin{tabular}{|c|c|c|c|c|c|c|c|c|c|c|c|c|}
\hline \multirow{2}{*}{ Directions } & \multicolumn{11}{|c|}{ P. cocoes (concentration in $\mu g^{-1}$ dry weight) } & \multirow{2}{*}{$\begin{array}{l}\text { Total } \\
\text { metal }\end{array}$} \\
\hline & $\mathrm{Cr}$ & Mn & $\mathbf{F e}$ & Co & $\mathrm{Ni}$ & $\mathrm{Cu}$ & $\mathrm{Zn}$ & As & Se & Cd & $\mathbf{P b}$ & \\
\hline North & BDL & BDL & BDL & BDL & BDL & BDL & BDL & BDL & BDL & BDL & BDL & BDL \\
\hline West & $60.07 \pm 0.17$ & $456.04 \pm 0.25$ & $32603.04 \pm 0.78$ & $13.11 \pm 0.67$ & $49.45 \pm 0.21$ & $53.23 \pm 0.23$ & $206.18 \pm 0.05$ & $14.0 \pm 0.37$ & $5.75 \pm 0.28$ & $3.32 \pm 0.23$ & $217.09 \pm 0.49$ & 33681.28 \\
\hline South & $49.7 \pm 0.95$ & $487.44 \pm 0.47$ & $26223.04 \pm 0.46$ & $10.9 \pm 0.05$ & $28.36 \pm 0.08$ & $28.53 \pm 0.11$ & $168.64 \pm 0.46$ & $19.56 \pm 0.19$ & $4.42 \pm 0.37$ & BDL & BDL & 27020.59 \\
\hline $\begin{array}{l}\text { Total } \\
\text { metal }\end{array}$ & 109.77 & 943.48 & 58826.08 & 24.01 & 77.81 & 81.76 & 374.82 & 33.56 & 10.17 & 3.32 & 217.09 & \\
\hline CV\% & 1.515 & 0.097 & 0.002 & 4.849 & 0.501 & 0.527 & 0.212 & 2.125 & 7.900 & 12.201 & 0.392 & \\
\hline $\begin{array}{l}\operatorname{LSD}(\mathbf{p}< \\
0.05 \%)\end{array}$ & $0.924 * *$ & $0.508^{* *}$ & $0.875^{* *}$ & $0.647 * *$ & $0.216^{* *}$ & $0.239 * *$ & $0.443^{* *}$ & $0.396^{* *}$ & $0.446^{* *}$ & $0.225^{* * *}$ & $0.473 * *$ & \\
\hline \multirow[t]{2}{*}{ Directions } & \multicolumn{11}{|c|}{$R$. sophodes (concentration in $\mu \mathrm{gg}^{-1}$ dry weight) } & \multirow{2}{*}{$\begin{array}{l}\text { Total } \\
\text { metal }\end{array}$} \\
\hline & $\mathrm{Cr}$ & Mn & $\mathbf{F e}$ & Co & $\mathbf{N i}$ & $\mathrm{Cu}$ & $\mathbf{Z n}$ & As & Se & Cd & $\mathbf{P b}$ & \\
\hline North & $87.13 \pm 0.52$ & $1281.04 \pm 0.58$ & $34703.04 \pm 0.57$ & $19.2 \pm 0.19$ & $61.91 \pm 0.31$ & $57.33 \pm 0.15$ & $154.38 \pm 0.17$ & $36.19 \pm 0.08$ & $6.62 \pm 0.17$ & $2.14 \pm 0.15$ & $441.09 \pm 0.41$ & 36850.07 \\
\hline West & $81.39 \pm 0.38$ & $1088.06 \pm 0.41$ & $34023.04 \pm 0.90$ & $21.34 \pm 0.30$ & $56.56 \pm 0.23$ & $56.33 \pm 0.09$ & $206.28 \pm 0.08$ & $28.92 \pm 0.30$ & $5.52 \pm 0.16$ & $2.37 \pm 0.16$ & $405.89 \pm 0.21$ & 35975.7 \\
\hline South & $1.11 \pm 0.13$ & $93.44 \pm 0.55$ & $156.54 \pm 0.49$ & $0.49 \pm 0.05$ & $3.88 \pm 0.13$ & $26.07 \pm 0.07$ & $108.78 \pm 0.21$ & $2.04 \pm 0.07$ & $2.03 \pm 0.03$ & $1.48 \pm 0.28$ & $39.09 \pm 0.04$ & 434.95 \\
\hline $\begin{array}{l}\text { Total } \\
\text { metal }\end{array}$ & 169.63 & 2462.54 & 68882.62 & 41.03 & 122.35 & 139.73 & 469.44 & 67.15 & 14.17 & 5.99 & 886.07 & \\
\hline CV\% & 0.673 & 0.063 & 0.023 & 1.499 & 0.577 & 0.226 & 0.102 & 0.811 & 2.850 & 6.744 & 0.089 & \\
\hline $\begin{array}{l}\operatorname{LSD}(p< \\
0.05 \%)\end{array}$ & $0.634 * *$ & $0.860^{* *}$ & $9.078^{* *}$ & $0.341^{* *}$ & $0.392 * *$ & $1.756^{* *}$ & $0.267^{* *}$ & $0.302 * *$ & $0.224 * *$ & $0.224 * *$ & $0.441 * *$ & \\
\hline
\end{tabular}

Mean $\pm S . D ., n=3$ in $\mu g^{-1}$ dry weight, $B D L=$ Below Detection Limit

** Significance at the level of $0.01 \%$.

* Significance at the level of $0.05 \%$ 
Table 4:- Values of correlation matrix between the elements found in lichen thalli around Panki Thermal Power Plant, Kanpur

\begin{tabular}{|c|c|c|c|c|c|c|c|c|c|c|c|}
\hline P.cocoes & $\mathbf{C r}$ & $\mathbf{M n}$ & $\mathbf{F e}$ & $\mathbf{C o}$ & $\mathbf{N i}$ & $\mathbf{C u}$ & $\mathbf{Z n}$ & $\mathbf{A s}$ & $\mathbf{S e}$ & $\mathbf{C d}$ & $\mathbf{P b}$ \\
\hline $\mathbf{C r}$ & 1 & 0.976 & $1.000^{*}$ & $1.000^{* *}$ & 0.962 & 0.949 & $1.000^{* *}$ & 0.904 & $.998^{*}$ & 0.633 & 0.633 \\
\hline $\mathbf{M n}$ & & 1 & 0.971 & 0.977 & 0.879 & 0.858 & 0.974 & 0.975 & 0.961 & 0.449 & 0.449 \\
\hline $\mathbf{F e}$ & & & 1 & $1.000^{*}$ & 0.968 & 0.956 & $1.000^{* *}$ & 0.894 & $.999^{*}$ & 0.651 & 0.651 \\
\hline $\mathbf{C o}$ & & & & 1 & 0.961 & 0.948 & $1.000^{* *}$ & 0.906 & $.998^{*}$ & 0.63 & 0.63 \\
\hline $\mathbf{N i}$ & & & & & 1 & $.999^{*}$ & 0.965 & 0.753 & 0.977 & 0.821 & 0.821 \\
\hline $\mathbf{C u}$ & & & & & & 1 & 0.952 & 0.724 & 0.967 & 0.845 & 0.845 \\
\hline $\mathbf{Z n}$ & & & & & & & 1 & 0.9 & $.999^{*}$ & 0.641 & 0.641 \\
\hline $\mathbf{A s}$ & & & & & & & & 1 & 0.877 & 0.242 & 0.242 \\
\hline $\mathbf{S e}$ & & & & & & & & & 1 & 0.679 & 0.679 \\
\hline $\mathbf{C d}$ & & & & & & & & & & 1 & $1.000^{* *}$ \\
\hline $\mathbf{P b}$ & & & & & & & & & & & 1 \\
\hline $\mathbf{R . s o p h o d e s}$ & $\mathbf{C r}$ & $\mathbf{M n}$ & $\mathbf{F e}$ & $\mathbf{C o}$ & $\mathbf{N i}$ & $\mathbf{C u}$ & $\mathbf{Z n}$ & $\mathbf{A s}$ & $\mathbf{S e}$ & $\mathbf{C d}$ & $\mathbf{P b}$ \\
\hline $\mathbf{C r}$ & 1 & 0.996 & $.999^{*}$ & 0.988 & $1.000^{*}$ & $1.000^{*}$ & 0.814 & 0.99 & 0.985 & 0.952 & $1.000^{*}$ \\
\hline $\mathbf{M n}$ & & 1 & 0.991 & 0.97 & $.998^{*}$ & 0.992 & 0.756 & $.999^{*}$ & 0.997 & 0.92 & $.997^{*}$ \\
\hline $\mathbf{F e}$ & & & 1 & 0.994 & $.998^{*}$ & $1.000^{* *}$ & 0.838 & 0.983 & 0.977 & 0.964 & $.998^{*}$ \\
\hline $\mathbf{C o}$ & & & & 1 & 0.984 & 0.993 & 0.893 & 0.956 & 0.948 & 0.988 & 0.985 \\
\hline $\mathbf{N i}$ & & & & & 1 & $.998^{*}$ & 0.799 & 0.993 & 0.989 & 0.944 & $1.000^{* *}$ \\
\hline $\mathbf{C u}$ & & & & & & 1 & 0.831 & 0.985 & 0.979 & 0.961 & $.999^{*}$ \\
\hline $\mathbf{Z n}$ & & & & & & & 1 & 0.722 & 0.702 & 0.953 & 0.802 \\
\hline $\mathbf{A s}$ & & & & & & & & 1 & $1.000^{*}$ & 0.898 & 0.992 \\
\hline $\mathbf{S e}$ & & & & & & & & & 1 & 0.886 & 0.988 \\
\hline $\mathbf{C d}$ & & & & & & & & & & 1 & 0.946 \\
\hline $\mathbf{P b}$ & & & & & & & & & & & 1 \\
\hline
\end{tabular}

*. Correlation is significant at the 0.05 level (2-tailed).

**. Correlation is significant at the 0.01 level (2-tailed).

\section{Comparative response of metal accumulation in $P$. cocoes and $R$. sophodes at different directions of Panki} Thermal Power Plant:-

Accumulation of eleven metals viz; Chromium (Cr), Manganese (Mn), Iron (Fe), Cobalt (Co), Nickel (Ni), Copper $(\mathrm{Cu})$, Zinc $(\mathrm{Zn})$, Arsenic (As), Selenium (Se), Cadmium $(\mathrm{Cd})$ and Lead $(\mathrm{Pb})$ were estimated in thalli of both lichens in all three directions from the Panki thermal power plant to compare the bioaccumulation of metals (Table-3). Both the species exhibited dissimilar sequence of concentration for all metals. Enhanced level of Fe clearly indicate vehicular activity as the originator (Pirintsos and Loppi, 2008). The study area showed higher accumulation of Fe, $\mathrm{Mn}, \mathrm{Zn}, \mathrm{Pb}$ metals, while $\mathrm{Cr}>\mathrm{Cu}>\mathrm{Ni}>\mathrm{As}>\mathrm{Co}>\mathrm{Se}>\mathrm{Cd}$ accumulated in lower concentration in both the species.

Lichens $P$. cocoes and $R$. sophodes showed accumulation of all the heavy metal within the ranges of 0.49 to $34703.04{\mu g g^{-1}}^{-1}$ dry weights as total metal contents. Both the species accumulated Fe in higher concentration followed by the sequence of $\mathrm{Mn}>\mathrm{Zn}>\mathrm{Pb}>\mathrm{Cr}>\mathrm{Cu}>\mathrm{Ni}>\mathrm{As}>\mathrm{Co}>\mathrm{Se}>\mathrm{Cd}$ with concentration of 58826.08, 943.48, $374.82,217.09,109.77,81.76,77.81,33.56,24.01,10.17$ and $3.32{\mu g^{-1}}^{-1}$ dry weight in P. cocoes. More or less similarly $R$. sophodes exhibit metal concentration sequence of $\mathrm{Fe}>\mathrm{Mn}>\mathrm{Pb}>\mathrm{Zn}>\mathrm{Cr}>\mathrm{Cu}>\mathrm{Ni}>\mathrm{As}>\mathrm{Co}>\mathrm{Se}>\mathrm{Cd}$ as 68882.62, 2462.54, 886.07, 469.44, 169.63,139.73, 122.35, 67.15, 41.03, 14.17 and $5.99 \mathrm{\mu gg}^{-1}$ dry weight (total metal) respectively. The $\mathrm{Pb}, \mathrm{Cr}, \mathrm{Ni}$ and $\mathrm{Cd}$ metals showed clear increasing trend of their concentrations in areas associated with high vehicular activities as well as coal burning.

Higher accumulation of Fe with concentration of 32603.04 $\pm 0.78{\mu \mathrm{gg}^{-1}}^{-1}$ in west site and minimum concentration of $26223.04 \pm 0.46 \mathrm{\mu gg}^{-1}$ in south clearly indicates that the wind direction may be the probable reason for the settling of this metal in south direction. Loppi et al. (1998a, b) and Bajpai et al. (2010b) also reported that Fe in the earth's crust are strongly correlated in lichens and environmental contamination and lichens have an especially affinity for Fe.

Manganese and As showed similar accumulation pattern as Mn ranged from $456.04 \pm 0.25 \mu^{-1}$ to $487.44 \pm 0.47$ $\mu \mathrm{gg}^{-1}$ and As ranged from $14.0 \pm 0.37 \mu \mathrm{gg}^{-1}$ to $19.56 \pm 0.19{\mu \mathrm{gg}^{-1}}^{-1}$ in west and south directions respectively. Zinc had 
maximum accumulation $\left(206.18 \pm 0.05 \mu \mathrm{gg}^{-1}\right)$ in west and minimum in south direction $\left(168.64 \pm 0.46 \mu \mathrm{gg}^{-1}\right)$. Higher concentration of $\mathrm{Zn}$ around the thermal power plant may be due to the high vehicular activity involved in the disposal of coal waste. Lubricant oil often contains $\mathrm{Cd}, \mathrm{Cu}$ and $\mathrm{Zn}$. Zinc may be emitted by automobile tires and brake pads (Berry and Wallace, 1981; Ward, 1989). Lead (Pb) and Cd showed their presence only in west direction with concentration of $217.09 \pm 0.49{\mu g g^{-1}}^{-1}$ and $3.32 \pm 0.23{\mu g g^{-1}}^{-1}$ respectively. The metal content exhibit descerasing trend at a distance of few kilometers from the source of pollution. Chromiun $(\mathrm{Cr}), \mathrm{Cu}$ and $\mathrm{Ni}$ showed similar range of accumulation of $49.7 \pm 0.95 \mu \mathrm{gg}^{-1}$ to $60.07 \pm 0.17 \mu \mathrm{gg}^{-1} ; 28.53 \pm 0.11 \mu \mathrm{gg}^{-1}$ to $53.23 \pm 0.23 \mathrm{\mu gg}^{-1}$ and $28.36 \pm 0.08$ $\mu \mathrm{gg}^{-1}$ to $49.45 \pm 0.21 \mu \mathrm{gg}^{-1}$ respectively. Some of the metals lighter in weight dispersed to long range while, according to Loppi et al. (1994), $\mathrm{Cu}$ is large particle metal emitted from the source are incapable of long-range dispersion. The concentration of metals of Co ranged between $\left(10.09 \pm 0.05 \mu \mathrm{gg}^{-1}\right.$ to $\left.13.11 \pm 0.67 \mu \mathrm{gg}^{-1}\right)$; Se $\left(4.42 \pm 0.37 \mu \mathrm{gg}^{-1}\right.$ to $5.75 \pm 0.28{\mu \mathrm{gg}^{-1}}^{-1}$ in south and west directions respectively. In $P$. cocoes, total metal concentration was highest in west $\left(33681.23 \mu \mathrm{gg}^{-1}\right)$ and lowest in south direction $\left(27020.59 \mu \mathrm{gg}^{-1}\right)$ of the study area but north direction showed all metals below detection limit (BDL).

R. sophodes exhibit higher concentration of total metals accumulated in north direction $\left(36850.07 \mu \mathrm{gg}^{-1}\right)$ followed by west direction (35975.7 $\mathrm{gg}^{-1}$ ) and south direction $\left(434.95 \mu \mathrm{gg}^{-1}\right)$. According to Garty (2001), Dispersion and distribution of metals depend on wind speed and direction as well as the density of the element under consideration. LSD analysis at $\mathrm{p}<0.01 \%$ level showed significant difference in chlorophyll estimation as well as protein content, while only chl. b showed significant differences at level of $0.05 \%$ (Table-3).

The correlation coefficient were calculated for concentration in paired element and for the element content in the lichen in different directions (Table-4). The possible source of element may be indicated by significant correlation between elements in the lichen thallus. The correlations (all significant at $\mathrm{p}<0.01$ level) of $\mathrm{Co}$ and $\mathrm{Cr}, \mathrm{Zn}$ and $\mathrm{Cr}, \mathrm{Zn}$ and $\mathrm{Fe}, \mathrm{Zn}$ and $\mathrm{Co}, \mathrm{Pb}$ and $\mathrm{Cr}$ in $\mathrm{P}$. cocoes but the correlations of $\mathrm{Cu}$ and $\mathrm{Fe}, \mathrm{Pb}$ and $\mathrm{Ni}$ in $R$. sophodes indicates motor vehicles as possible originators (Table-4). Nickel is found in car metal using plating in welded plates (Ward, 1989) and in tires (Sadiq et al., 1989). Among the eleven metals analyzed, $\mathrm{Cu}, \mathrm{Pb}$ and $\mathrm{Zn}$ seems to cause extensive damage to the biological apparatus by causing alteration in the vital physiological process (Shukla and Upreti, 2008).

\section{Conclusion:-}

Both $P$. cocoes and $R$. sophodes at all the sites showed more or less similar selectivity sequence of metals and similar chlorophyll degradation with positive correlation matrix; whereas protein content had positively correlated in $P$. cocoes and negatively correlated with all photosynthetic parameters in $R$. sophodes. The level of concentration of different metal present in the lichens provide information about the risk to the population living in the vicinity of the power plant together with long-term hazard due to metal accumulation. The reason for the higher accumulation of metals may be due to anthropogenic activities together with pollutants emerging from thermal power due to coal burning.

Since the area is close to Panki thermal power plants, therefore, the probable source of metals in species may be attributed to the emission of thermal power plant. The study provided an understanding about the mechanisms adopted by different growth form of lichens for bioaccumulation of metals emitted by thermal power plant and indicates that the particulate bound adsorption is the major factor responsible for bioaccumulation in lichens irrespective of their growth form.

The physiological studies carried out on lichens together with metal accumulation, degradation of chlorophyll and change in protein and carotenoid will help to understand the damage caused by the pollutants to the living organisms around thermal power plant. The study also provide baseline data on levels of metal accumulation around the thermal power plant which will be helpful for carrying out future biomonitoring studies in the area.

\section{Acknowledgements:-}

The authors are thankful to the Head, Department of Environmental Science, BBAU, Lucknow and Director, CSIRNational Botanical Research Institute, Lucknow for providing laboratory facilities. One of the authors (Namita Gupta) is grateful to University Grant Commission, New Delhi for financial support by providing Senior Research Fellowship (SRF). 


\section{References:-}

1. Arnon, D.I. (1949): Copper enzyme in isolated chloroplast polyphenoloxidases in Beta vulgaris, Plant Physiol., 24: 1-15.

2. Bajpai, R., Karakoti, N. and Upreti, D.K. (2013b): Performance of a naturally growing Parmeloid lichen Remototrachyna awasthii against organic and inorganic pollutants. Environ. Sci. Pollut. Res., 20 : $5577-5592$.

3. Bajpai, R., Shukla, V. and Upreti, D.K. (2013a): Impact assessment of anthropogenic activities on air quality, using lichen Remototrachyna awasthii as biomonitor. Int. J. Environ. Sci. Technol., 10(6): 1287- 1294.

4. Bajpai, R., Upreti, D.K. and Mishra, S.K. (2004): Pollution monitoring with the help of lichen transplant technique at some residential sites of Lucknow. J. Environ. Biol., 25: 191-195.

5. Bajpai, R., Upreti, D.K. and Nayaka, S. (2010b): Accumulation of arsenic and fluoride in Lichen Pyxine cocoes (Sw.) Nyl., growing in the vicnicity of coal- based thermal power plant at Raebareli, India. J. of Experimental Sciences. 1(4): 37- 40.

6. Bajpai, R., Upreti, D.K., Nayaka, S. and Kumari, B. (2010a): Biodiversity, bioaccumulation and physiological changes in lichens growing in the vicinity of coal-based thermal power plant of Raibareily district, North India. J. of Hazardous Materials, 174: 429-436.

7. Bargagli- Pertrucci, G. (1915): Studi sulla flora miscroscopica della regione boracifera della Toscana. La vegetazione crittogamina nella regione boracifera. Giorn. Bot. Ital., 22: 409-411.

8. Berry, W.L. and Wallace A. (1981): Toxicity: The concept and relationship to the close response curve, J. Plant Nutr., 3: 13-19.

9. Burton, M.A.S. (1986): Biological monitoring of environmental contaminants (plants). MHRC Report Number 32, Monitoring \& assessment research centre, King's College London, University of London.

10. Carreias, H.A., Gudino, D. and Pignata, M.L. (1998): Comparative biomonitoring of atmospheric quality in five zones of Cordoba city (Argentia) employing the transplanted lichen Usnea sp, Environ. Pollut., 103: $317-325$.

11. Cicek, A., Koparal, A.S., Catak, S. and Ugur S. (2001): The level of some heavy metals and nutritional elements in the samples from soils and trace levels growing in the vicinity of Syitomer Thermal power plant in Kutahya (Turkey), in : S. Topcu et al., (Eds), Air Quality Management at Urban, Regional and Global scales, Istanbul, Turkey, pp. 157- 162.

12. Dubey, A.K., Pandey, V., Upreti, D.K. and Singh, J. (1999): Accumulation of lead by lichens growing in and around Faizabad city, U.P., India', Journal of Environmental Biology, 20(3): 223-225.

13. Garty, J. (2001): Biomonitoring atmospheric heavy metals with lichens: Theory and application. Critical Reviews in Plant Sciences, 20(4): 309-371.

14. Garty, J., Weissman, L., Tamir, O., Beer, S., Cohen, Y., Karnieli, A. and Orlovsky, L. (2000): Comparison of five physiological parameters to assess the vitality of the lichen Ramalina lacera exposed to air pollution. Physiol. Plant., 109: 410-418.

15. Gonzaléz, C.M., Casanovas, S.S. and Pignata, M.L. (1996): Biomonitoring of air pollutants from traffic and industries employing Ramalina ecklonii (Spreng.) Mey. and Flot in Cordoba Argentina. Environmental Pollution, 91, 269-277.

16. Gupta, N., Gupta, V., Dwivedi, S.K. and Upreti, D.K. (2015): Comparative bioaccumulation potential of Pyxine cocoes and Bacidia submedialis in and around Faizabad city, Uttar Pradesh, India. G- Journal of Environmental Science and Technology (G-JEST), 2(6): 86-92.

17. Gupta, V. (2014): Air Pollution Monitoring in and around Faizabad city utilizing lichen distribution pattern. M. Sc. Dissertation. Department of Environmental Science, Dr. R.M.L. Avadh University, Faizabad.

18. Loppi, S., Putorti, E., Signorini, C., Fommei, S., Pirintsos, S.A. and De Dominicis, V. (1998b): A retrospective study using epiphytic lichens as biomonitors of air quality: 1980 and 1996 (Tuscany, central Italy). Acta Oecol., 19: 405-408.

19. Loppi, S., Cenni, E., Bussotti, F. and Ferretti, M. (1998a): Biomonitoring of geothermal air pollution by epiphytic lichens and forest trees. Chemosphere, 36: 1079-1082.

20. Loppi, S., Chiti, F., Corsini, A. and Bernardi, L. (1994): Lichen biomonitoring of trace metals in the Pistoia area (central northern Italy). Environ. Monit. Assess., 29: 17-27.

21. Lowry, O.H. and Rosebrough, N.J. (1951): Farr AL and Randall RJ. Protein measurement with the folin phenol reagent. J. Biol. Chem., 193: 265-275.

22. Mishra, S.K., Upreti, D.K., Pandey, V. and Bajpai, R. (2003): Pollution monitoring with the help of lichen transplant technique in some commercial and industrial areas of Lucknow city. Pollution Research, 22(2): 221225.

23. Neumann, D., Lichtenberger, O., Gunther, D., Tschiersch, K. and Nover, L. (1994): Heat-stock proteins induce heavy metal tolerance in plants. Planta, 194: 360-367. 
24. Orange, A., James, P.W. and White, F.J. (2001): Micro chemical Methods for the Identification of Lichens. British Lichen Society, UK.

25. Pandey, V., Upreti, D.K., Pathak, R. and Pal, A. (2002): Heavy metal accumulation in lichens from the Hetauda Industrial area, Narayani zone, Nakwanpur District, Nepal. Environ. Monit. Assess., 73(3): 221-228.

26. Parsons, T.R., Maita, Y. and Lalli, C.M. (1984): A manual of chemical and biological methods for seawater analysis, Oxford, Pergamon.

27. Pirintsos, S.A. and Loppi, S. (2008): Biomonitoring atmospheric pollution: the challenge of times in environmental policy on air quality, Environ. Pollut., 151: 269-271.

28. Purvis, O.W., Chimonides, P.J., Jones, G.C., Mikhailova, I.N., Sipro, B., Weiss, D.J. and Williamson, B.J. (2004): Lichen biomonitoring near karabash smelter town, ural Mountains, Russia, one of the most polluted areas in world, Proc. R. Soc. Lond. 271: 221-226.

29. Ronrn, R. and Galun, M. (1984): Pigment extraction from lichens with dimethyl sulfoxide (DMSO) and estimation of chlorophyll degradation. Environ. Exp. Bot., 24:239-245.

30. Sadiq, M., Alam, I., El-Mubarek, A. and Al-Mohdar, H.M. (1989): Preliminary evaluation of metal pollution from wear of auto tires. Bulletin of Environmental Contamination Toxicology, 42: 743-748.

31. Satya and Upreti, D.K. (2009): Correlation among carbon, nitrogen, sulphur and physiological parameters of Rinodina sophodes found at Kanpur city, India. Journal of Hazardous Materials, 169: 1088-1092.

32. Satya and Upreti, D.K. (2015): Air Quality Assessment by Rinodina sophodes with Reference to Seasonal Variation and Traffic Influence in India. International Journal of Current Microbiology and Applied Sciences, 4 (9): 549-559.

33. Saxena, S., Upreti, D.K. and Sharma, N. (2007): Heavy metal accumulation in lichens growing in north side of Lucknow city, India. Journal of Environ. Biology, 28(1): 49-51.

34. Shukla, V. and Upreti, D.K. (2007a): Heavy metal accumulation in Phaeophyscia hispidula en route to Badrinath, Uttaranchal, India. Environ. Monit. Assess., 131(1-3): 365-369.

35. Shukla, V. and Upreti, D.K. (2007b): Physiological response of lichen Phaeophyscia hispidula (Ach.) Essl., to the urban environment of Pauri and Srinagar (Garhwal), Himalayas, India', Environ. Pollut., 150 (3): $295-299$.

36. Shukla, V. and Upreti, D.K. (2008): Effect of metallic pollutants on the physiology of lichen, Pyxine subcinerea Stirton in Garhwal Himalaya, Envir. Monit. Assess., 141(1-3): 237-243.

37. Singh, J., Agrawal, M. and Narayan, D. (1994): Effect of power plant emission on plant community structure, Ecotoxicology, 3: 110-122.

38. Upreti, D.K. and Pandey, V. (2000): Determination of heavy metals in lichens growing on different ecological habitats in Schirmacher Oasis, East Antarctica. Spectr. Lett., 33: 435-444.

39. Ward, N.I. (1989): Multi element contamination of British motor way environments, in: J.P. Vernet (Ed.), Heavy Metals in the Environment. International Conference, vol. II, Geneva, CEP, Edinburgh, pp. $279-282$. 